\title{
POTENTIAL OF THE PHYSIOLOGICAL RESPONSE OF PEA PLANTS (Pisum sativum L.) TO IRON DEFICIENCY (DIRECT OR LIME- INDUCED)
}

\author{
POTENCIAL DA RESPOSTA FISIOLÓGICA DAS PLANTAS DE ERVILHA \\ (Pisum sativum L.) À DEFICIÊNCIA DE FERRO (DIRETA OU INDUZIDA PELO \\ CALCÁRIO)
}

\author{
Jihed FERHI $^{1.2}$; Mohamed GHARSALLI ${ }^{1}$; Chedly ABDELLY ${ }^{1}$; Abdelmajid KROUMA ${ }^{1}$ \\ 1. Laboratory of Extremophile Plants, Centre of Biotechnology of Borj Cedria, Tunisia. abdelmajid.krouma@ gmail.com; 2. Faculty of \\ Sciences of Tunis, Tunisia.
}

\begin{abstract}
Pea (Pisum sativum L.) is an important food crop in Tunisia, where calcareous soils represents the major limiting factor for agriculture production. In the present study a greenhouse experiment was conducted to assess the effects of direct and bicarbonate- induced iron deficiency on plant growth, chlorophyll fluorescence, photosynthesis, spad index and iron nutrition in two Tunisian pea genotypes (Pisum sativum L.). Plants were grown hydroponically and iron deficiency was induced for 3 weeks. Iron deficiency decreased all the above physiological parameters. The direct Fe deficiency is more drastic than bicarbonate- induced Fe deficiency. A close relationship between plant growth, photosynthesis and SPAD index was observed. Fe use efficiency for plant growth and Fe use efficiency for photosynthesis discriminates clearly the studied genotypes and seems to be the main reason of the tolerance of Kelvedon, as compared to Lincoln.
\end{abstract}

KEYWORDS: Chlorophyll fluorescence- Fe use efficiency- iron deficiency- photosynthesis- Spad index.

\section{INTRODUCTION}

In calcareous soils, which constitute the major part of cultivated land, the soil solution does not provide more than $10 \%$ of the plant requirements for Fe (MORTVEDT, 1991). The total $\mathrm{Fe}$ content in these soils is high but the available fraction for the plant is insufficient. This is caused by the very low solubility of iron oxides at the alkaline $\mathrm{pH}$ conditions that are buffered by the presence of bicarbonate in these soils. Ammari and Mengel (2006) indicated that $\mathrm{Fe}$ concentration found in calcareous soil was high enough to meet the plant's demand and prove that $\mathrm{Fe}$ chlorosis on such soils is not a question of the Fe availability in the soil.

Iron $(\mathrm{Fe})$ is known to be essential for many physiological and biochemical processes such as: photosynthesis, respiration, DNA synthesis, nitrogen assimilation and symbiotic nitrogen fixation and participates in the electron transfer through reversible redox reactions, cycling between $\mathrm{Fe}^{2+}$ and $\mathrm{Fe}^{3+}$. Fe deficiency affects the structure, development and function of the entire photosynthetic apparatus (ABADIA et al., 1999). It has been shown that $\mathrm{Fe}$ deficiency decreases lightharvesting pigments, particularly chlorophylls (MORALES et al., 2000), and promotes antenna disconnection in PSII (MORALES et al., 2001). Furthermore, Fe-deficient leaves show lower PSII efficiency and a decrease in the proportion of open PSII reaction centers (qp ) (LARBI et al., 2006).
Salahi et al. (2017) demonstrated that foliar iron sprays improve the performance of oriental plane tree in calcareous soil better than soil treatments.

Differences among species and genotypes in plant response to iron deficiency have been reported. Krouma et al. (2008) and Slatni et al. (2009) reported clear genotypic differences in the response of common bean to iron deficiency. Soybean seed yield decreased by $20 \%$ per unit of visual leaf chlorosis (FeDC) when grown on calcareous soil (FROEHLICH; FEHR, 1981). Various authors reported that $\mathrm{Fe}$ resupply to deficient plants restores many plant functions. For instance, it leads within a few days to increases in chlorophyll concentration and photosynthetic activity in several annual species, including sugar beet (LARBI et al., 2004) and tobacco (PUSHNIK; MILLER, 1989). Paula et al. (2016) observed in Lotus japonicus that interveinal chlorosis was associated with a reduced $\mathrm{Fe}^{2+}$ shoot content in all sensitive ecotypes and a decline in photosynthesis rate and PSII performance compared to the control. In some apple cultivars, bicarbonate treatment reduced active and total $\mathrm{Fe}$ and total chlorophyll concentrations, and FCR (leaf ferric chelate reductase) activity (SAHIN et al., 2017)

The objective of this study was to examine the physiological parameters associated with the tolerance of pea to iron deficiency in order to establish useful test for screening program, and to assess the relationships between plant growth, 
SPAD index, photosynthesis, chlorophyll fluorescence and iron nutrition.

\section{MATERIALS AND METHODS}

\section{Plant material and experimental conditions}

Two pea genotypes were used, Kelvedon and Lincoln largely cultivated in the North and North West of Tunisia. Seeds were disinfected with $2 \%$ hypochlorite calcium solution then rinsed in deionized water. Germination was made in Petri dishes containing moistened filter paper for 6 days at $20{ }^{\circ} \mathrm{C}$. Seven-day-old seedlings were then transferred to a half strength aerated nutrient solution for 7 days and then similar sized seedlings were selected and cultured as groups of 10 plants in $10 \mathrm{~L}$ of full strength aerated nutrient solution.

The composition of the nutrient solution was: $1.25 \mathrm{mM} \mathrm{Ca}\left(\mathrm{NO}_{3}\right)_{2}, 1.25 \mathrm{mM} \mathrm{KNO}_{3}, 0.5 \mathrm{mM}$ $\mathrm{MgSO}_{4}, 0.25 \mathrm{mM} \mathrm{KH} \mathrm{PO}_{4}$ and $10 \mu \mathrm{M} \mathrm{H}_{3} \mathrm{BO}_{3}, 1 \mu \mathrm{M}$ $\mathrm{MnSO}_{4}, 0.5 \mu \mathrm{M} \mathrm{ZnSO}, 0.05 \mu \mathrm{M}\left(\mathrm{NH}_{4}\right)_{6} \mathrm{Mo}_{7} \mathrm{O}_{24}$ and $0.4 \mu \mathrm{M} \mathrm{CuSO}_{4}$. Three treatments were established for 21 days as follows: control (solution added with $30 \mu \mathrm{M}$ Fe: C), direct iron deficiency (no iron added) and bicarbonate-induced iron deficiency (solution added with $30 \mu \mathrm{M} \mathrm{Fe}+0.5 \mathrm{~g} \mathrm{~L}^{-1} \mathrm{CaCO}_{3}+$ $10 \mathrm{mM} \mathrm{NaHCO}$ ). Iron was supplied in the form of $\mathrm{Fe}(\mathrm{III})$-EDTA. $\mathrm{NaHCO}_{3}$ and $\mathrm{CaCO}_{3}$ were added to the nutrient solution to simulate the natural condition in calcareous soil. Aerated hydroponic cultures were maintained in a growth chamber with a day/ night regime of $16 / 8 \mathrm{~h}, 24 / 18{ }^{\circ} \mathrm{C}$ and a relative humidity of $70 \%$. The solution was renewed every 2 days.

After 21 days of treatments, SPAD index, chlorophyll fluorescence and gas exchange parameters were measured, and then plants were separated into shoots and roots, dried at $60{ }^{\circ} \mathrm{C}$ for 72 hours, and then pulverized into a fine powder.

\section{SPAD Index}

The degree of chlorosis was estimated nondestructively in the youngest fully expanded apical leaves from five plants of each treatment using a portable SPAD-502 meter (Minolta, Osaka, Japan). Five SPAD readings were recorded for each leaf, homogeneously distributed from the apex to the base of the leaf, to obtain a representative degree of leaf chlorosis.

\section{Active iron}

Measurements of active iron $\left(\mathrm{Fe}^{2+}\right)$ were performed according to Köseoglu and Acikgöz (1995) The extraction was made in $25 \mathrm{mg}$ of leaves fine powder shacked in $10 \mathrm{ml}$ of $1 \mathrm{~N} \mathrm{HCl}$.

\section{Gas exchange measurement}

Gas exchange measurements were made with an LI-6400 (LI-COR, Inc.) portable gas exchange system. Measurements were made on the 3 youngest fully expanded leaves. Photosynthesis was induced with saturating light $\left(1000 \mu \mathrm{mol} \mathrm{m}^{-2} \mathrm{~s}^{-}\right.$ $\left.{ }^{1}\right)$. This light was fitted to the standard $6-\mathrm{cm}^{2}$ clamp on the leaf chamber. Sample $\mathrm{pCO}_{2}$, flow rate, and temperature were kept constant at 362 mbar, 500 $\mu$ mol. $\mathrm{s}^{-1}$, and $25^{\circ} \mathrm{C}$, respectively.

\section{Chlorophyll fluorescence measurements}

Prior to the measurements, the attached leaves were dark adapted for 30min in leaf-clips. Values for maximum fluorescence $\left(\mathrm{F}_{\mathrm{m}}\right)$ and initial fluorescence $\left(\mathrm{F}_{0}\right)$ from the fluorescence induction curve were measured with a portable chlorophyll fluorometer (OS1-FL). Photosynthetic photon flux density (PPFD) was lower than $0.4 \mu \mathrm{mol} \mathrm{m} \mathrm{m}^{-2}$ at the leaf surface. $F_{m}$ was measured at $20 \mathrm{kHz}$ with a $0.8 \mathrm{~s}$ pulse of $6000 \mu \mathrm{mol} \mathrm{m} \mathrm{m}^{-2} \mathrm{~s}^{-1}$ of white light (Morales et al., 1998).

\section{Calculations}

Fe use efficiency for plant growth (FeUEDW) was expressed as the ratio of biomass production to $\mathrm{Fe}$ accumulation in leaves $[\mathrm{g}$ dry weight. $\left.\mu \mathrm{mol}^{-1} \mathrm{Fe}\right]$ and $\mathrm{Fe}$ use efficiency for net assimilation (FeUEAn) was expressed as the ratio of net assimilation to Fe accumulated in leaves $[(\mu \mathrm{mol}$ $\left.\left.\mathrm{CO}_{2} \mathrm{~m}^{-2} \mathrm{~s}^{-1}\right) \cdot \mu \mathrm{mol}^{-1} \mathrm{Fe}\right]$.

\section{Statistical analysis}

Variance analysis of data (one-way ANOVA) was performed using the SPSS 10.0 program, and means were separated to Duncan's test at $p \leq 0.05$. Data shown are means of five repetitions (photosynthetic parameters, SPAD index and chlorophyll fluorescence) or nine (Biomass and $\mathrm{Fe}$ content) replicates for each treatment.

\section{RESULTS}

\section{Plant growth and SPAD index}

All plants subjected to iron deficiency exhibited a clear decrease of biomass production. This effect was more important when plants are cultivated on Fe- free medium. Nevertheless, the negative effect of iron deficiency on plant growth is more pronounced in Lincoln than Kelvedon. The decrease of biomass production was estimated to $8 \%$ and $40 \%$ in Lincoln subjected to direct or bicarbonate- induced $\mathrm{Fe}$ deficiency, respectively; and $9 \%$ and $17 \%$ in Kelvedon subjected to direct or 
bicarbonate- induced Fe deficiency, respectively (fig $1)$.

The SPAD index values (table 1) followed the same scheme of variation of plant growth parameters. Iron deficiency decreased SPAD index, the effect is more drastic in direct than indirect $\mathrm{Fe}$ deficiency. Kelvedon remain the less affected genotype as compared to Lincoln. The values of SPAD index decreased with $11 \%$ and $16 \%$ in Kelvedon and with $24 \%$ and $28 \%$ in Lincoln, respectively subjected to direct or bicarbonateinduced iron deficiency.

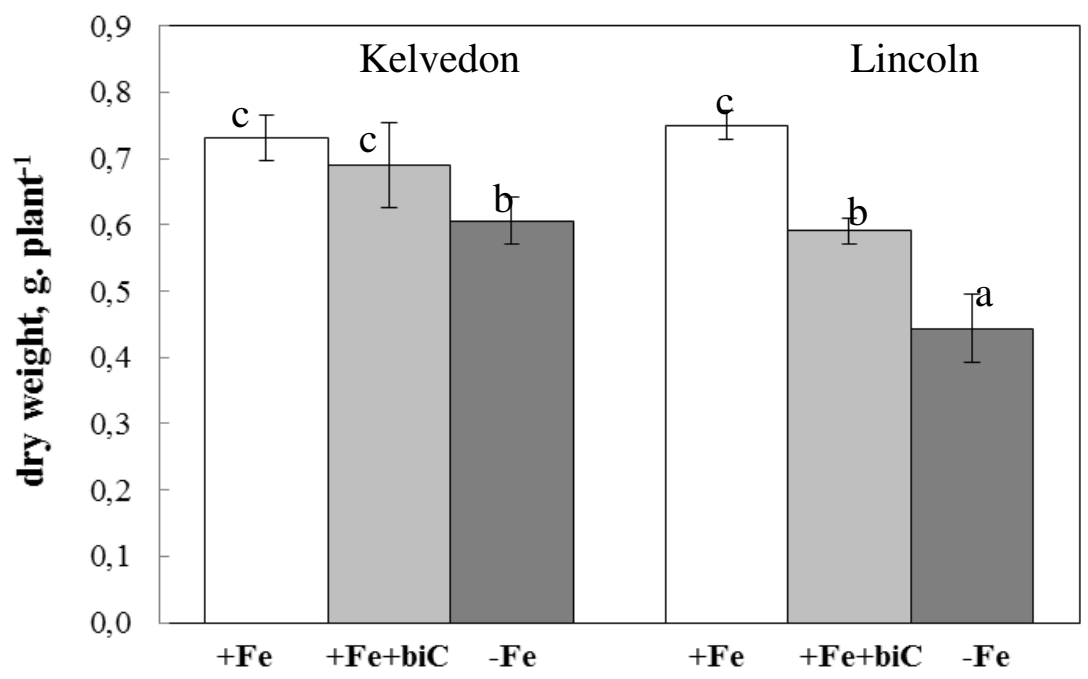

Figure 1. Biomass production in pea plants subject to bicarbonate- induced or direct iron deficiency. Vertical bars represent \pm standard errors of means of 9 replicates, $\mathrm{p} \leq 0.05$.

Table 1. SPAD index in leaves of two pea genotypes subjected direct $(-\mathrm{Fe})$ or bicarbonate- induced $(+\mathrm{Fe}+\mathrm{biC})$ Fe deficiency compared to control treatment $(+\mathrm{Fe})$. Standard errors of means of 9 replicates, $\mathrm{p} \leq 0.05$.

\begin{tabular}{l|c|c|c|c}
\hline \multirow{2}{*}{ SPAD Index } & Genotypes & $+\mathbf{F e}$ & $\mathbf{+ F e}+\mathbf{b i C}$ & $\mathbf{- F e}$ \\
\cline { 2 - 4 } & Kelvedon & $38.56 \pm 0.85$ & $34.33 \pm 0.95$ & $32.4 \pm 1.63$ \\
\cline { 2 - 4 } & Lincoln & $39.76 \pm 0.86$ & $30.33 \pm 1.56$ & $28.66 \pm 0.97$ \\
\hline
\end{tabular}

Photosynthesis and chlorophyll fluorescence Iron deficiency decreased net photosynthesis in the two studied genotypes. Independently of iron deficiency origin, this effect was less pronounced in Kelvedon than Lincoln (fig 2 ). In the first genotype $A_{n}$ decreased by $15 \%$ in plants subjected to induced $\mathrm{Fe}$ chlorosis $(+\mathrm{Fe}+\mathrm{biC})$ and by $32 \%$ in plants subjected to direct $\mathrm{Fe}$ chlorosis $(-\mathrm{Fe})$. In the second genotype (Lincoln), this decrease was estimated to $34 \%$ in plants suffering from induced $\mathrm{Fe}$ chlorosis and $49 \%$ in plants suffering from direct Fe deficiency.

Concerning the other photosynthetic parameters, the same trend of variation was observed. Direct or induced Fe chlorosis decreased transpiration (fig 3a), stomatal conductance (fig 3b). The lack of iron in the medium is more drastic than its deficiency induced by bicarbonate. Kelvedon remain the less affected genotype as compared to Lincoln. 


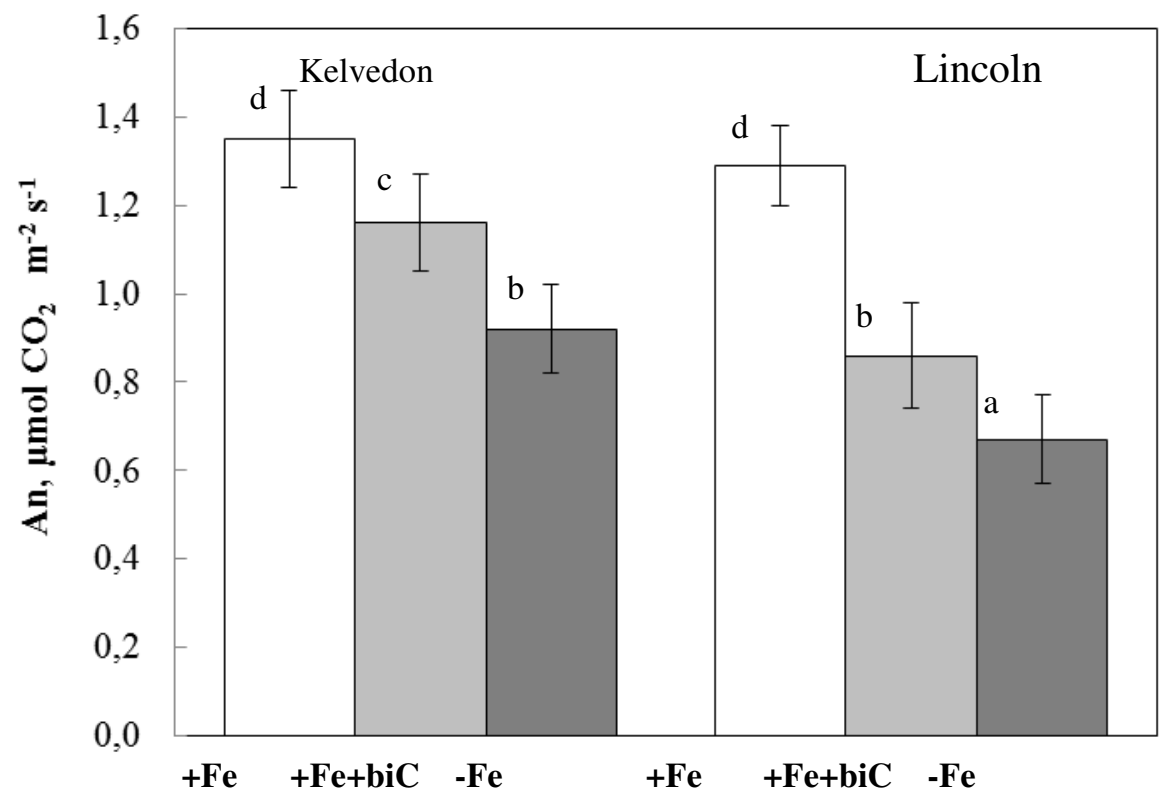

Figure 2. Net assimilation (An) in two pea genotypes subjected to direct $(-\mathrm{Fe})$ or induced $\mathrm{Fe}$ chlorosis $(+\mathrm{Fe}$ + biC) as compared to control treatment $(+\mathrm{Fe})$. Vertical bars represent \pm standard errors of means of 5 replicates, $\mathrm{p} \leq 0.05$.

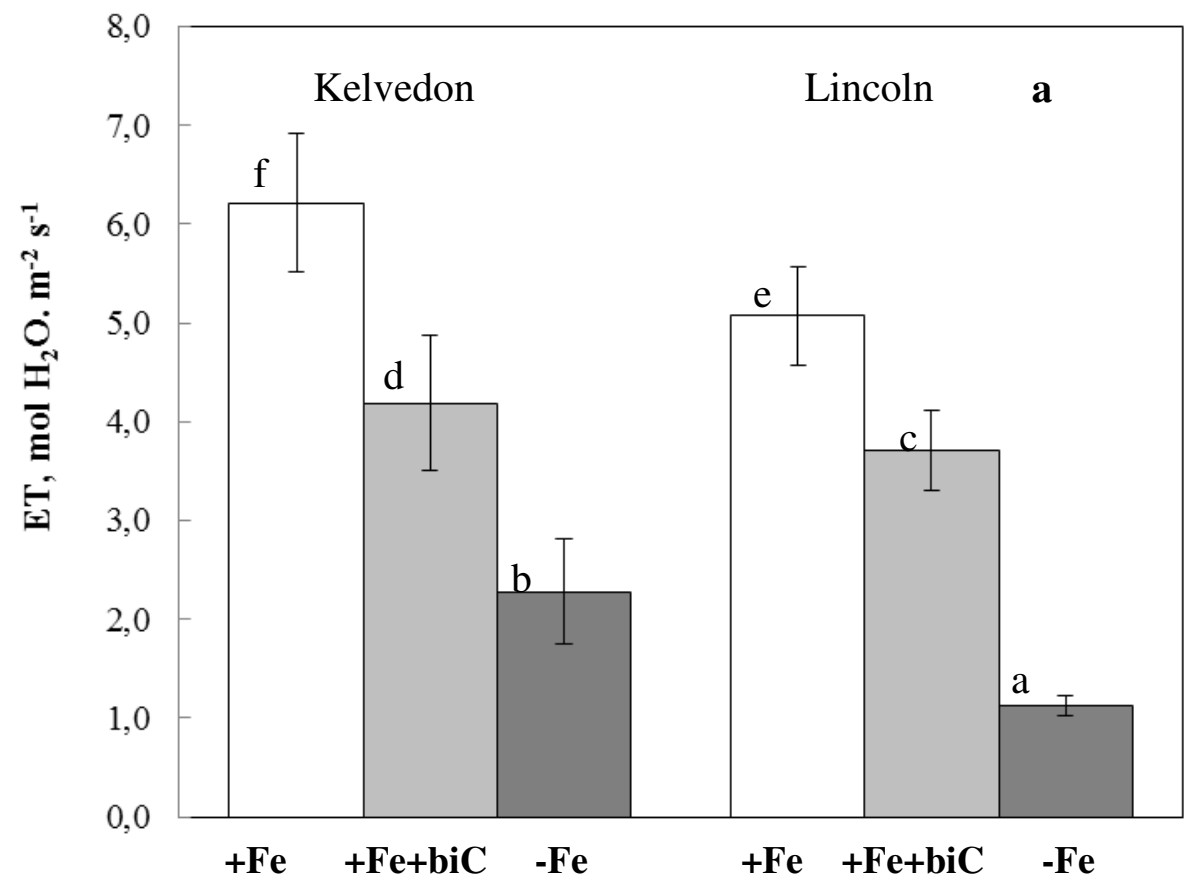

Figure 3a. Evapotranspiration (ET) in two pea genotypes subjected to direct (-Fe) or induced Fe chlorosis $(+\mathrm{Fe}$ + biC) as compared to control treatment $(+\mathrm{Fe})$. Vertical bars represent \pm standard errors of means of 5 replicates, $\mathrm{p} \leq 0.05$. 


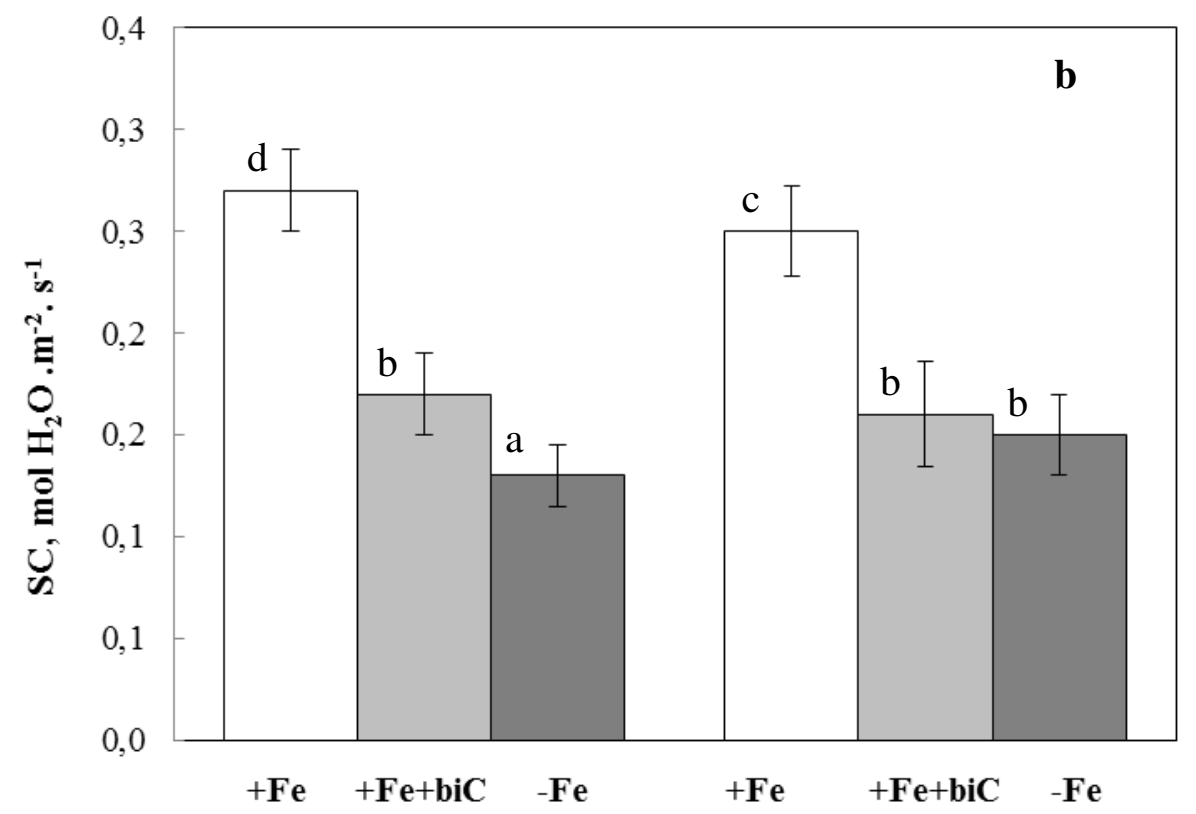

Figure 3b. Stomatal Conductance (SC) in two pea genotypes subjected to direct (-Fe) or induced $\mathrm{Fe}$ chlorosis $(+\mathrm{Fe}+\mathrm{biC})$ as compared to control treatment $(+\mathrm{Fe})$. Vertical bars represent \pm standard errors of means of 5 replicates, $\mathrm{p} \leq 0.05$.

For internal concentration of $\mathrm{CO}_{2}$ (fig 4), a slight decrease of this element was observed under iron deficiency but without significant effect.

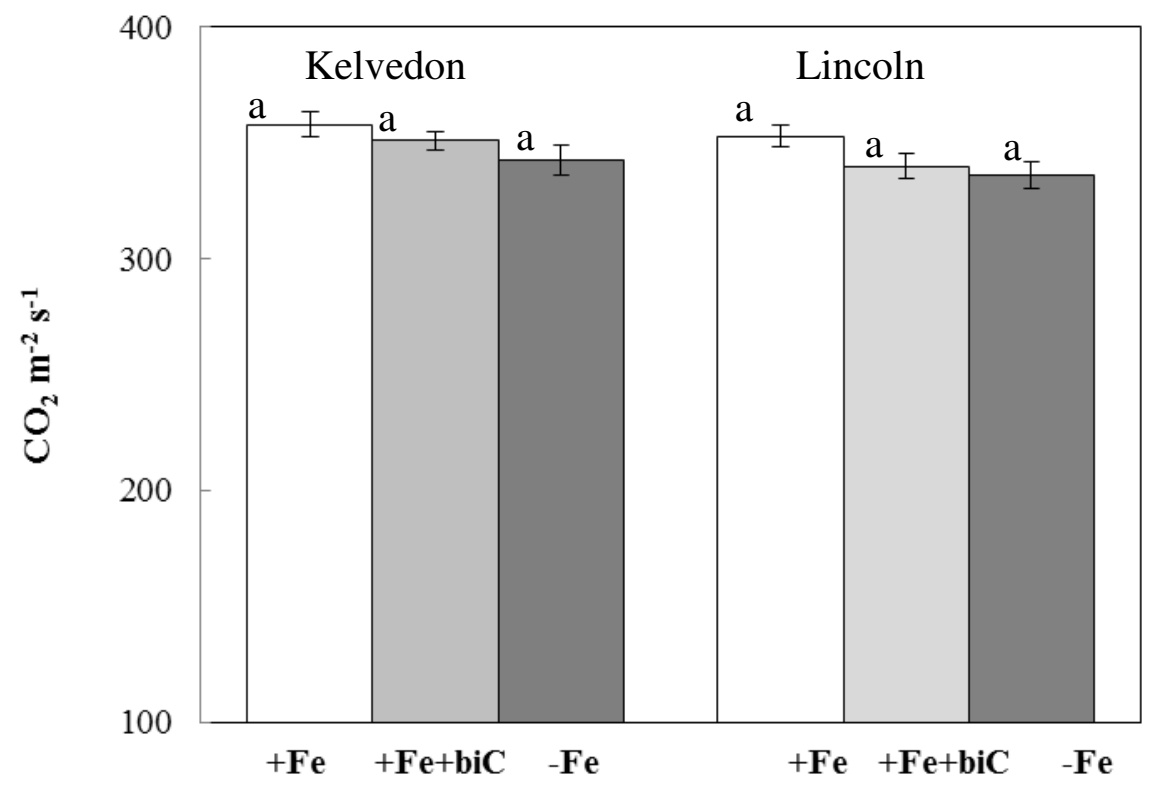

Figure 4. Internal $\mathrm{CO}_{2}$ concentration in two pea genotypes subjected to direct (-Fe) or induced $\mathrm{Fe}$ chlorosis $(+\mathrm{Fe}+\mathrm{biC})$ as compared to control treatment $(+\mathrm{Fe})$. Vertical bars represent \pm standard errors of means of 5 replicates, $\mathrm{p} \leq 0.05$.

Measurements made on chlorophyll fluorescence demonstrate important genotypic differences in the maximum quantum yield of PSII in dark as in light test (table 2). In fact, no significant effect of direct and induced $\mathrm{Fe}$ chlorosis observed in Kelvedon. However, in Lincoln genotype, iron deficiency induced a clear decrease of $\mathrm{Fv} / \mathrm{Fm}$ (- $8 \%$ in bicarbonate- induced and $-12 \%$ in direct iron deficiency) and F'v/F'm (- 9\% in bicarbonate- induced and $-10 \%$ in direct iron 
deficiency). The calculation of non- photochemical quenching (NPQ) demonstrates an important effect of iron deficiency in Lincoln (- $10 \%$ in bicarbonateinduced and $-21 \%$ in direct iron deficiency) but not in Kelvedon ( $-6 \%$ only in direct iron deficiency) (table 2).

Table 2. Maximum quantum yield of PSII (Fv/Fm and F'v/F'm) and non - photochemical quenching (NPQ) in two pea genotypes subjected direct $(-\mathrm{Fe})$ or bicarbonate- induced $(+\mathrm{Fe}+\mathrm{biC}) \mathrm{Fe}$ deficiency compared to control treatment $(+\mathrm{Fe})$. Standard errors of means of 5 replicates, $\mathrm{p} \leq 0.05$.

\begin{tabular}{c|c|c|c|c}
\hline & Genotypes & $\mathbf{+} \mathbf{F e}$ & $\mathbf{+} \mathbf{F e}+\mathbf{b i C}$ & $\mathbf{F e}$ \\
\hline \multirow{2}{*}{ Fv/Fm } & Kelvedon & $0,76 \pm 0.03$ & $0,76 \pm 0.02$ & $0,74 \pm 0.01$ \\
\cline { 2 - 5 } & Lincoln & $0,79 \pm 0.02$ & $0,73 \pm 0.01$ & $0,69 \pm 0.02$ \\
\hline \multirow{2}{*}{ F'v/F'm } & Kelvedon & $0,60 \pm 0.03$ & $0,58 \pm 0.02$ & $0,59 \pm 0.01$ \\
\cline { 2 - 5 } & Lincoln & $0,60 \pm 0.02$ & $0,54 \pm 0.01$ & $0,53 \pm 0.02$ \\
\hline \multirow{2}{*}{$\mathbf{N P Q}$} & Kelvedon & $2.51 \pm 0.02$ & $2.57 \pm 0.03$ & $2.35 \pm 0.03$ \\
\cline { 2 - 5 } & Lincoln & $2.71 \pm 0.03$ & $2.44 \pm 0.03$ & $2.13 \pm 0.02$ \\
\hline
\end{tabular}

\section{Iron nutrition}

The analysis of the extractible active fraction of Fe in leaves (fig 5) demonstrated that iron deficiency induced a significant decrease of this micronutrient. When subjected to induced Fe chlorosis, this decrease was estimated to $35 \%$ and
$33 \%$, respectively in Kelvedon and Lincoln, while reaching $54 \%$ and $52 \%$, respectively in Kelvedon and Lincoln, subjected to direct iron deficiency. This result indicated a clear problem of iron allocation to leaves. 


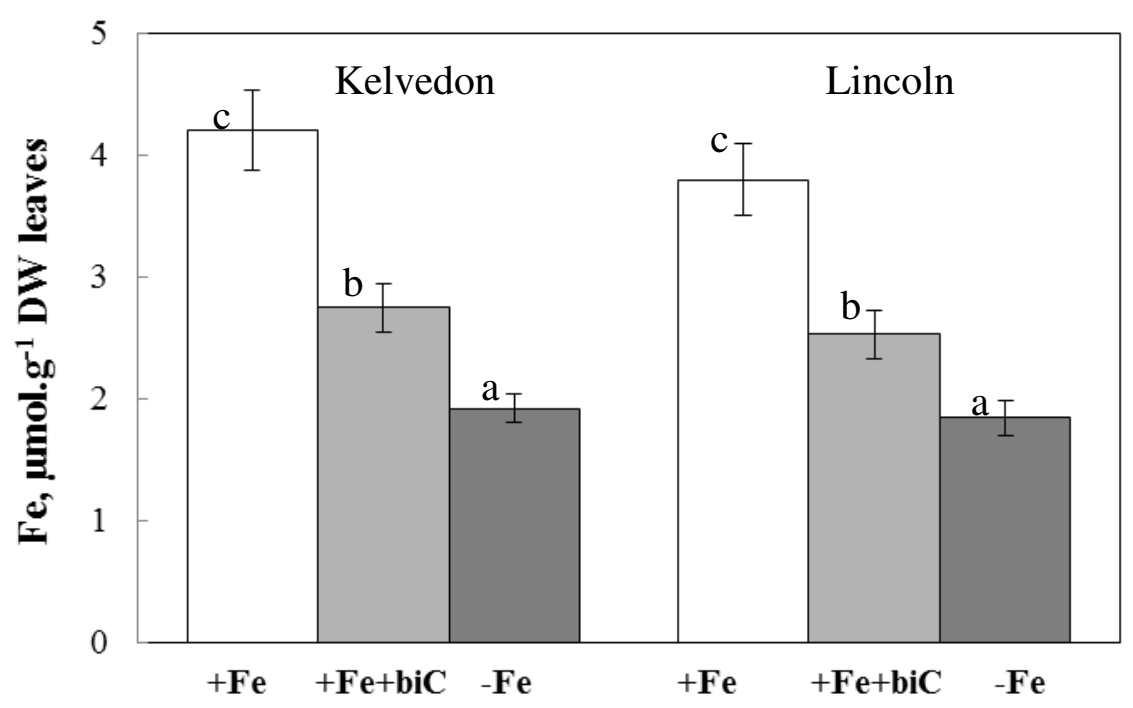

Figure 5. Active iron (FeII) concentrations in leaves of pea genotypes subjected to direct (-Fe) or induced $\mathrm{Fe}$ chlorosis $(+\mathrm{Fe}+\mathrm{biC})$ as compared to control treatment $(+\mathrm{Fe})$. Vertical bars represent \pm standard errors of means of 9 replicates, $p \leq 0.05$. DW: dry weight

The calculation of the Fe use efficiency for plant growth and photosynthetic activity demonstrated that this parameter increased with iron deficiency in Kelvedon and remain without significant changes in Lincoln (table 3). The first genotype expressed higher efficiency of $\mathrm{Fe}$ use in $\mathrm{Fe}$ depletion conditions as compared to Lincoln.

Table 3. Fe use efficiency for plant growth (FeUEDW, expressed as the ratio of biomass production to Fe accumulation in leaves, g DW. $\mu \mathrm{mol}^{-1} \mathrm{Fe}$ ) and Fe use efficiency for net assimilation (FeUEAn, calculated as the ratio of net assimilation to $\mathrm{Fe}$ accumulated in leaves), in two pea genotypes subjected to direct or induced Fe deficiency.

\begin{tabular}{l|c|c|c|c}
\hline \multirow{2}{*}{ FeUE DW } & Genotypes & $\mathbf{+ F e}$ & $\mathbf{+ F e + b i C}$ & $\mathbf{- F e}$ \\
\cline { 2 - 5 } & Kelvedon & $0.40 \pm 0.04$ & $0.78 \pm 0.05$ & $1.12 \pm 0.09$ \\
& Lincoln & $0.32 \pm 0.03$ & $0.66 \pm 0.07$ & $0.82 \pm 0.07$ \\
\hline \multirow{2}{*}{ FeUE An } & Kelvedon & $0.73 \pm 0.06$ & $1.15 \pm 0.08$ & $1.71 \pm 0.09$ \\
\cline { 2 - 5 } & Lincoln & $0.55 \pm 0.04$ & $0.96 \pm 0.09$ & $1.23 \pm 0.11$ \\
\hline
\end{tabular}

\section{DISCUSSION}

Typically, $\mathrm{Fe}$ and $\mathrm{P}$ are the two main nutrients that limit plant growth on calcareous soils (MARSCHNER, 1995). Our results show that iron deficiency decreased biomass production and SPAD index in the two studied genotypes and significantly inhibit active iron (FeII) accumulation. Direct Fe deficiency is more drastic than bicarbonate- induced Fe deficiency and Lincoln is usually more affected than Kelvedon. As documented by several authors (ZOCCHI et al., 2007; KROUMA et al., 2008), Fe 
deficiency adversely affected plant growth and shoot length in several plant species. In fact, $\mathrm{Fe}$ is known to be essential for many physiological and biochemical processes such as: photosynthesis, respiration, DNA synthesis, nitrogen assimilation and symbiotic fixation. iron is shown indispensable element for chlorophyll and carotenoids biosynthesis (THOIRON et al., 1997), the photosynthesis (JELLELI et al., 2011) as well as the metabolism of plastidial proteins (SPENCE et al., 1991) and therefore, the induced iron chlorosis and the decrease of SPAD index observed in this study can be explained by a drastic decrease of iron availability for these organs. İncesu et al. (2015) observed significant differences in SPAD and iron chlorosis scale reading between rootstocks and $\mathrm{Fe}$ treatments. In fact, fig 6 which correlates the leaves Fe content with their SPAD index demonstrated a close relationship between these two parameters $\left(\mathrm{R}^{2}=0.99\right)$. The genotypic variability observed in this study was found in common bean subjected to iron deficiency (KROUMA et al., 2008). It has been shown that Fe deficiency decreased light-harvesting pigments, particularly chlorophylls (MORALES et al., 2000); and promotes antenna disconnection in PSII (MORALES et al., 2001; MOSELEY et al.,
2002). Furthermore, many micronutrients (e.g. Fe, $\mathrm{Mn}, \mathrm{Cu}$ and $\mathrm{Zn}$ ) that are freely available in acid soils are only sparingly available in calcareous soils, due to their poor solubility at high $\mathrm{pH}$ (BRADY and WEIL, 1999). Experiments have shown calcifuges plants (those which cannot establish well on calcareous soils e.g. pea and common bean) to be primarily excluded from growth in calcareous soils due to poor $\mathrm{P}$ and $\mathrm{Fe}$ use efficiency (KERLEY et al., 2001). The calculation of the Fe use efficiency for plant growth (FeUEDW, table 3) expressed as the ratio of biomass production to $\mathrm{Fe}$ accumulation in leaves (g DW. $\mu \mathrm{mol}^{-1} \mathrm{Fe}$ ) screened clearly the studied genotypes. The values of FeUEDW where 2 times more important in bicarbonate- induced Fe deficiency plants as compared to control one's and 3 times in direct $\mathrm{Fe}$ deficiency. The most attractive result at this level is that Kelvedon develop more important efficiency of iron use than Lincoln with the same quantities of iron accumulated in leaves when subjected to iron deficiency. The FeUEDW is 1.2 and 1.4 times higher in Kelvedon than Lincoln when subjected to induced and direct $\mathrm{Fe}$ deficiencies, respectively. This efficiency seems to be the origin of Kelvedon tolerance.

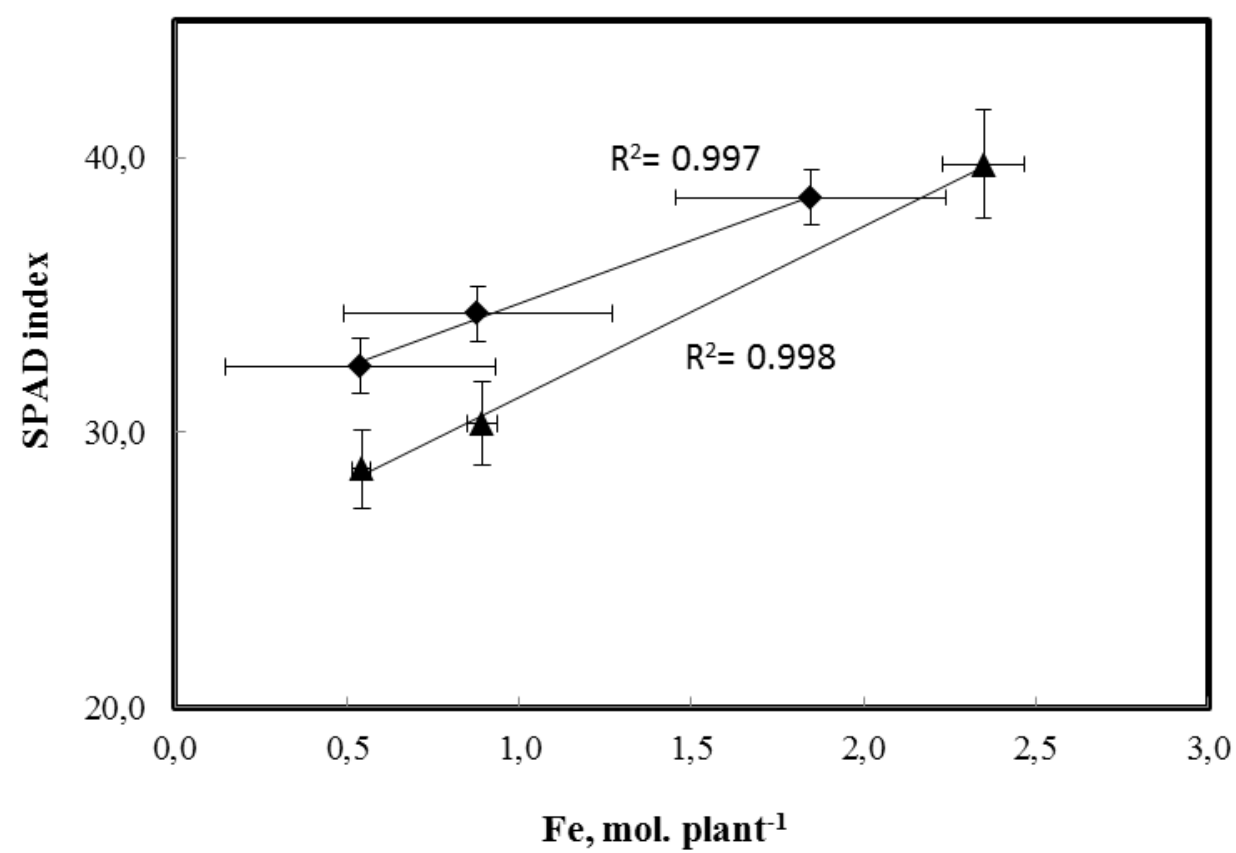

Figure 6. Relationship between active iron (FeII) concentrations in leaves and SPAD index in two pea genotypes subjected to induced or direct iron deficiency.

The measurements made on gas exchange parameters and chlorophyll fluorescence show that independently of its origin, iron deficiency decreased net assimilation and other photosynthetic parameters. The maximum quantum yield of PSII is significantly affected by iron deficiency in Lincoln but not in Kelvedon. Genotypic differences previously observed were maintained and Kelvedon 
develops a better preservation of its photosynthetic apparatus. Previous works demonstrated that the maximum quantum yield of photosystem II decreased in $\mathrm{Fe}$ deficient leaves of citrus (PESTANA et al., 2005), pear (DONNINI et al., 2009) and peach rootstocks (MOLASSIOTIS et al., 2006). Similar results were found by Donnini et al. (2009) showing different reorganization of the photosynthetic apparatus between tolerant and sensitive genotypes of pear and quince cultivated in the presence of bicarbonate. In addition, Sharma (2007) investigated the adaptation of photosynthesis under Fe deficiency in maize plants and suggested an involvement of nuclear- chloroplast signaling in mediating adaptive changes in the photosynthetic machinery triggered by redox status and possibly, accumulation of chlorophyll biosynthesis intermediates. Kara (2016) concluded that low temperature, high net photosynthesis rate, high internal $\mathrm{CO}_{2}$ concentration/ambient $\mathrm{CO}_{2}$ ratio and low transpiration rate might be used as reliable selection criteria in further triticale breeding programs. In the present study, the calculation of Fe use efficiency for photosynthesis (FeUEAn, calculated as the ratio of net assimilation to $\mathrm{Fe}$ accumulated in leaves, $\mu \mathrm{mol} \mathrm{CO}_{2} \mathrm{~m}^{-2} \mathrm{~s}^{-1} \cdot \mu \mathrm{mol}^{-1} \mathrm{Fe}$ ) (table 3), demonstrated a clear increase of this parameter in plants subjected to iron deficiency. Kelvedon maintain its performance, as compared to Lincoln, in the two Fe deficiency origin with values of FeUEAn 1.4 times more important than lincoln.

It appears clearly that FeUEDW and FeUEAn discriminates the two studied pea genotypes. The better efficiency of Kelvedon genotype, compared to Lincoln one, gives us a new explanation of its performance in a limiting iron availability condition like calcareous soil. In fact, our results suggested that the tolerance of Kelvedon is probably linked to two parameters: firstly a better ability to allocate more iron to shoots to maintain photosynthetic activity and plant growth; and secondly, to its efficiency of iron use. We suggest that Fe use efficiency for plant growth and Fe use efficiency for photosynthesis might be used as reliable selection criteria in further plant breeding programs.

RESUMO: A ervilha (Pisum sativum L.) é uma cultura alimentar importante na Tunísia, onde os solos calcários representam o principal fator limitante para a produção agrícola. No presente estudo, foi conduzido um experimento em estufa para avaliar os efeitos da deficiência de ferro direta e induzida por bicarbonato sobre o crescimento de plantas, a fluorescência da clorofila, a fotossíntese, o índice SPAD e a nutrição de ferro em dois genótipos de ervilha da Tunísia (Pisum sativum L.). As plantas foram cultivadas hidroponicamente e a deficiência de ferro foi induzida durante 3 semanas. A deficiência de ferro diminuiu todos os parâmetros fisiológicos acima. A deficiência de Fe direta é mais drástica do que a deficiência de Fe induzida por bicarbonato. Observou-se uma estreita relação entre o crescimento das plantas, a fotossíntese e o índice SPAD. A eficiência de uso de Fe para o crescimento de plantas e a eficiência de uso de Fe para a fotossíntese discriminam claramente os genótipos estudados e parecem ser a razão principal da tolerância de Kelvedon, em comparação com a de Lincoln.

PAlAVRAS-CHAVE: Fluorescência de clorofila. Eficiência de uso de Fe. Deficiência de ferro. Fotosíntese. Índice Spad.

\section{REFERENCES}

ABADIA, J. F.; MORALES, A.; ABADIA, J. Photosystem II efficiency in low chlorophyll iron- deficient leaves. Plant Soil, v. 215, p. 183-192, 1999. https://doi.org/10.1023/A:1004451728237

AMMARI, A.; MENGEL, K. Total soluble Fe in soil solutions of chemically different soils. Geoderma, V. 136, P. 876- 885, 2006. https://doi.org/10.1016/j.geoderma.2006.06.013

BRADY, N. C.; Weil, R. R. The Nature and Properties of Soils. $12^{\text {th }}$ ed. Prentice Hall Inc., New Jersey, 1999.

CAMPESTRE, M. P. ; ANTONELli, C.; CALZADILlA, P. I.; MAIALE, S. J.; RODRIGUEZ, A. A. ; RUIZ, O. A. The alkaline tolerance in Lotus japonicus is associated with mechanisms of iron acquisition and modification of the architectural pattern of the root. Journal of Plant Physiology, v. 206, p. 40-48, 2016. https://doi.org/10.1016/j.jplph.2016.09.005 
DONNINI, S.; CASTAGNA, A.; RANIERI, A.; ZOCCHI, G. Differential responses in pear and quince genotypes induced by Fe deficiency and bicarbonate. Journal of Plant Physiology, v. 166, p. 1181- 1193, 2009. https://doi.org/10.1016/j.jplph.2009.01.007

FROEHLICH, D. M.; FEHR, W. R. Agronomic performance of soybeans with differing levels of iron deficiency chlorosis on calcareous soil. Crop Sciences, v. 21, p. 438-441, 1981.

https://doi.org/10.2135/cropsci1981.0011183X002100030021x

INCESU, M. T.; YESILOGLU, B.; CIMEN, B.; YILMAZ, B. Influences of different iron levels on plant growth and photosynthesis of $\mathrm{W}$. Murcott mandarin grafted on two rootstocks under high $\mathrm{pH}$ conditions. Turkish Journal of Agriculture and Forestry, v. 39, p. 838- 844, 2015. https://doi.org/10.3906/tar-1501-25

JELALI, N., BEN SALAH, I.; M'SEHLI, W.; DONNINI, S.; ZOCCHI, G.; GHARSALLI, M. 2011. Comparison of three pea cultivars (Pisum sativum) regarding their responses to direct and bicarbonate-induced iron deficiency. Scientia Horticulturae, v. 129, p. 548- 553, 2011.

https://doi.org/10.1016/j.scienta.2011.06.010

KARA, R. Evaluation of flag leaf physiological traits of Triticale genotypes under eastern Mediterranean conditions. Turkish Journal of Field Crops, v. 21, n. 1, p. 67- 78, 2016. https://doi.org/10.17557/tjfc.66594

KERLEY, S. J.; SHIELD, L. F.; HUYGHE, C. Specific and genotypic variation in the nutrient content of lupin species in soils of neutral and alkaline pH. Australian Journal of Agricultural Research, v. 52, p. 93- 102, 2001. https://doi.org/10.1071/AR00060

KOSEOGLU, A. T.; ACIKGOZ, V. Determination of iron chlorosis with extractable iron analysis in peach leaves. Journal of Plant Nutrition, v. 18, p. 153- 161, 1995. https://doi.org/10.1080/01904169509364892

KROUMA, A.; SLATNI, T.; ABDELLY, C. Differential tolerance to lime-induced chlorosis of N2- fixing common bean (Phaseolus vulgaris L.). Symbiosis, p. 137- 143, 2008.

LARBI, A.; ABADIA, A.; MORALES, F.; ABADIA, J. Fe resupply to Fe deficient sugar beet plants leads to rapid changes in the violaxanthin cycle and other photosynthetic characteristics without de novo chlorophyll synthesis. Photosynthesis Research, v. 79, p. 59- 69, 2004.

https://doi.org/10.1023/B:PRES.0000011919.35309.5e

LARBI, A., ABADIA, A.; ABADIA, J.; F. MORALES, F. Down co-regulation of light absorption, photochemistry, and carboxylation in Fe-deficient plants growing. in different environments. Photosynthesis Research, v. 89, p. 113-126, 2006. https://doi.org/10.1007/s11120-006-9089-1

MARSCHNER, H. Mineral Nutrition of Higher Plants. Academic Press, London, 1995.

MOLASSIOTIS, A.; TANOU, G.; DIAMANTIDIS, G.; PATAKAS, A.; THERIOS, I. Effects of 4 month Fe deficiency exposure on Fe reduction mechanism, photosynthetic gas exchange, chlorophyll fluorescence and antioxidant defense in two peach rootstocks differing in Fe deficiency tolerance. Journal of Plant Physiology, v. 163, p. 176-185, 2006. https://doi.org/10.1016/j.jplph.2004.11.016

MORALES, F.; ABADIA, A.; ABADIA, J. Photosynthesis, quenching of chlorophyll fluorescence and thermal energy dissipation in iron-deficient sugar beet leaves. Australian Journal of Plant Physiology, v. 25, p. 403412, 1998. https://doi.org/10.1071/PP97130

MORALES, F., BELKHODJA, R.; ABADIA, A.; ABADIA, J. Photosystem II efficiency and mechanisms of energy dissipation in iron-deficient, field-grown pear trees (Pyrus communis L.). Photosynthesis Research, v. 63, p. 9-21, 2000. https://doi.org/10.1023/A:1006389915424 
MORALES, F., MOISE, N.; QUILEZ, R.; ABADIA, A. ; ABADIA, J. ; MOYA, I. Iron deficiency interrupts energy transfer from a disconnected part of the antenna to the rest of Photosystem II. Photosynthesis Research, v. 70, p. 207- 220, 2001. https://doi.org/10.1023/A:1017965229788

MORTVEDT, J. J. Correcting iron deficiencies in annual and perennial plants: Present technologies and future prospects. Plant Soil, v. 130, p. 273-279, 1991. https://doi.org/10.1007/BF00011883

PESTANA, M.; CORREIA, P. J.; SAAVEDRA, T.; GAMA, F.; ABADIA, A.; DE VARENNES, A. Development and recovery of iron deficiency by iron resupply to roots or leaves of strawberry plants. Plant Physiology and Biochemistry, v. 53, p. 1- 5, 2012. https://doi.org/10.1016/j.plaphy.2012.01.001

PESTANA, M.; DE VARENNES, A.; ABADIA, J.; FARIA, E. A. Differential tolerance to iron deficiency of citrus rootstocks grown in nutrient solution. Scientia Horticulturae, v. 104, p. 25- 36, 2005.

https://doi.org/10.1016/j.scienta.2004.07.007

PUSCHNIK, J. C.; MILLER, G. W. Iron regulation of chloroplasts photosynthetic function: mediation of PS I development. Journal of Plant Nutrition, v. 4, p. 407- 421, 1989.

https://doi.org/10.1080/01904168909363962

SAHIN, O. ; GUNES, A.; TASKIN, M. B.; INAL, A. Investigation of responses of some apple (Mallus $x$ domestica Borkh.) cultivars grafted on MM106 and M9 rootstocks to lime-induced chlorosis and oxidative stress. Scientia Horticulturae, v. 219, p. 79-89, 2017. https://doi.org/10.1016/j.scienta.2017.03.006

SALAHI, B.; HADAVI, E.; SAMAR, S. M. Foliar iron sulphate-organic acids sprays improve the performance of oriental plane tree in calcareous soil better than soil treatments. Urban Forestry \& Urban Greening, v. 21, p. 175-182, 2017. https://doi.org/10.1016/j.ufug.2016.12.001

SHARMA, S. Adaptation of photosynthesis under iron deficiency in maize. Journal of Plant Physiology, v. 164, p. 1261- 1267, 2007. https://doi.org/10.1016/j.jplph.2007.02.004

SLATNI, T.; KROUMA, A.; GOUIA, H.; ABDELLY, C. Importance of ferric chelate reductase activity and acidification capacity in root nodules of N2-fixing common bean (Phaseolus vulgaris L.) subjected to iron deficiency. Symbiosis, v. 47, p. 35- 42, 2009. https://doi.org/10.1007/BF03179968

SPENCE, M. J.; HENZL, M. T.; LAMMERS, P. J. The structure of a Phaseolus vulgaris cDNA encoding the iron storage protein ferritin. Plant Molecular Biology, v. 117, p. 499- 504, 1991.

https://doi.org/10.1007/BF00040644

THOIRON, S.; PASCAL, N.; BRIAT, J. F. Impact of iron deficiency and iron re-supply during the early stages of vegetative development in maize (Zea mays L.). Plant Cell Environment, v. 20, p. 1051-1060, 1997. https://doi.org/10.1111/j.1365-3040.1997.tb00681.x

ZOCCHI, G., De NISI, P.; DELL'ORTO, M.; ESPEN, L.; GALLINA, P. M. Iron deficiency differently affects metabolic responses in soybean roots. Journal of Experimental Botany, v. 58, p. 993- 1000, 2007.

https://doi.org/10.1093/jxb/erl259 